\title{
Aspekty ojcostwa Bożego w wybranych perykopach Mateuszowych
}

\section{Summary}

Ojciec opowiada się za ludźmi prostymi. Objawia im więź istniejącą między Nim a Synem i jednocześnie zakrywa ją przed pychą uczonych (11,25-27). Ojciec powinien spotykać się z bojaźnią ze strony ludzi, ponieważ rozstrzyga o ostatecznym losie człowieka. Wzmianka o możliwości definitywnego odrzucenia przez Ojca zostaje złagodzona Jego troską i wiedzą o każdym szczególe życia człowieka (10, 28-31). Z faktu, że Bóg jest Ojcem, wynika powszechne braterstwo łączące uczniów, które nie ma nic wspólnego z jakąkolwiek formą zależności. Uczniowie są bowiem zależni jedynie od Ojca w niebie $(23,9)$.

Słowa kluczowe: ukrywać, objawiać, bać się, jeden Ojciec

\section{Streszczenie}

\section{Aspects of the Fatherhood of God in the Selected Pericopes of St Mathew's Gospel}

The Father advocates the simple and humble. He reveals the bond between Him and the Son, and at the same time hides it from the pride of the scribes (11,25-27). The Father should meet with a respectful fear of the people because He ultimately decides on the fate of man. The note of the possibility of definitive rejection by the Father is mitigated by His care for and knowledge of every detail of human life (10, 28-31). From the fact that God is the Father can be derived an apparent common brotherhood that connects disciples which has nothing to do with any form of dependency. The disciples are only dependent on the Father in heaven $(23,9)$.

Keywords: to hide, to reveal, to fear, one Father

1 Stanisław Witkowski MS (ORCID: 0000-0002-7282-1866) - ks. dr hab., adiunkt w katedrze egzegezy Nowego Testamentu na Uniwersytecie Jana Pawła II w Krakowie. Interesuje się zagadnieniami synoptycznymi, Pawłowymi oraz apokaliptycznymi. Adres do korespondencji: ul Koszalińska 12, 30-407 Kraków. E-mail: stwit@op.pl. 
Ewangelia Mateuszowa poświęca wiele miejsca Bożemu ojcostwu. Sło-

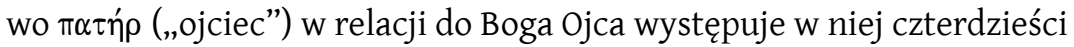
cztery razy. W Ewangelii Markowej spotykamy tego typu odniesienie zaledwie cztery razy, w Łukaszowej zaś siedemnaście razy². Już samo to zestawienie świadczy, że Mateusz wśród synoptyków najbardziej zwraca uwagę na Boga jako Ojca. Ewangelię Mateuszową można zatem nazwać Ewangelią o Ojcu. Określenie „Ojciec” przewija się w niej w sumie w szesnastu rozdziałach ${ }^{3}$, a największą jego częstotliwość dostrzegamy w Kazaniu na Górze, gdzie termin „Ojciec” występuje aż siedemnaście razy, w zaledwie trzech rozdziałach (5-7)4.

W niniejszym opracowaniu zwrócimy uwagę jedynie na pewne aspekty dotyczące Bożego ojcostwa ${ }^{5}$, zawarte w wybranych przez nas tekstach: Mt 11, 25-27; 10, 28-31; 23, 9. Dlatego też wnioski okażą się jedynie pewnymi sugestiami. Będą domagać się potwierdzenia i uzupełnienia badaniami wszystkich miejsc w Ewangelii Mateuszowej, w których do-

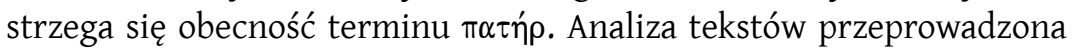
zostanie w ujęciu kanonicznym, które postrzega Biblię jako harmonijną całość.

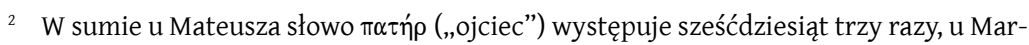
ka osiemnaście razy, u Łukasza zaś pięćdziesiąt sześć razy.

Jedynie w rozdziałach $1-4 ; 8 ; 9 ; 14 ; 17 ; 19 ; 21 ; 22 ; 27$ nie ma odniesienia do Ojca.

4 Zagadnienia związane z Bogiem Ojcem w Kazaniu na Górze zostały przedstawione w sposób syntetyczny w: S. Witkowski, Nowa jakość życia. Kazanie na Górze (Mt 5-7), Kraków 2004.

5 Na temat Bożego Ojcostwa w Ewangelii Mateusza nie mamy zbyt wielu opracowań. Wśród istniejących należy wymienić: J. Łach, Określenie Boga Ojcem w Ewangelii św. Mateusza, w: Ty, Panie, jesteś naszym Ojcem (Iz 64, 7). Biblia o Bogu Ojcu, red. F. Mickiewicz, J. Warzecha, Warszawa 1999, s. 70-80 (Rozprawy i Studia Biblijne, 5); P. Kasiłowski, Bądźcie doskonali, jak doskonaty jest Ojciec wasz niebieski (Mt5, 48). Naśladowanie Ojca w Ewangelii Mateusza, w: Ty, Panie, jesteś naszym Ojcem (Iz 64, 7). Biblia o Bogu Ojcu, dz. cyt., s. 187-204 (Rozprawy i Studia Biblijne, 5); H. Langkammer, Ojciec niebieski naszym Ojcem w Ewangelii św. Mateusza, w: H. Langkammer, Bóg jako Ojciec w świetle Nowego Testamentu, Radom 1999, s. 112-125. Ogólnie zaś na temat Boga Ojca w Nowym Testamencie piszą m.in.: A. Kwas, Bóg Ojcem w Nowym Testamencie, „Ruch Biblijny i Liturgiczny" 35 (1982) nr 3, s. 186-193; M. Rosik, Teologia Nowego Testamentu, t. 1: Ewangelie synoptyczne i Dzieje Apostolskie, Wrocław 2008, s. 25-50. 


\section{Doksologia Jezusa na cześć Ojca (Mt 11, 25-26)}

W perykopie Mt 11, 25-27 Jezus zwraca się w modlitwie do Ojca za pomocą formuły dość często występującej w tradycji biblijnej: „wysławiam Cię" (por. np. Rdz 29, 35; 2 Sm 22, 50; Ps 9, 2; 111 (110), 1; 138 (137), 1. 4;

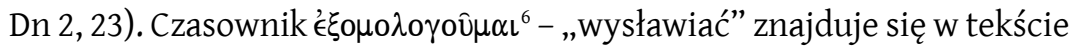
w stronie zwrotnej i oznacza „ogłaszać” w sensie uwielbienia i dziękczynienia. Jezus uwielbiając Ojca, jednocześnie Mu dziękuje ${ }^{7}$.

Ojciec jako adresat uwielbienia jest nazwany „Panem nieba i ziemi”. Wyjątkowość tego określenia wyraża się w jego jednorazowym zastosowaniu w całym Nowym Testamencie (por. Dz 4, 24; Ap 10, 6; 14, 7). Niebo i ziemia streszczają cały wszechświat. Ojciec jest zatem Panem całego uniwersum, obdarzającym - zgodnie z Tb 7,17 - radością i odwagą. To, co się wydarza, podlega Jego suwerennej woli.

Motywem uwielbienia skierowanego do Ojca są Jego dwa działania

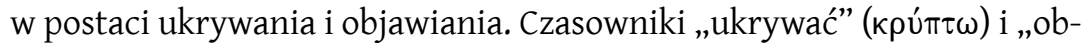

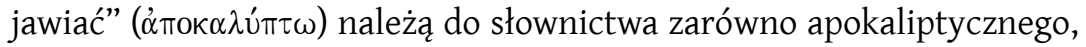
jak i sapiencjalnego ${ }^{9}$ W analizowanym tekście odnoszą się do dwóch przeciwstawnych grup: z jednej strony dotyczą mądrych i inteligentnych, z drugiej zaś - dzieci.

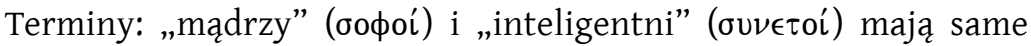
w sobie wydźwięk bardzo pozytywny. W Dn LXX 2, 21 czytamy, że Bóg

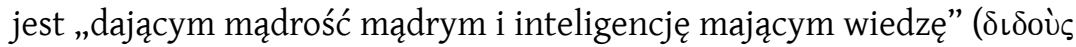

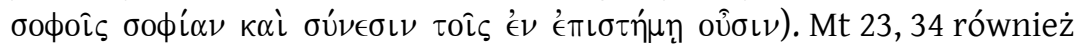

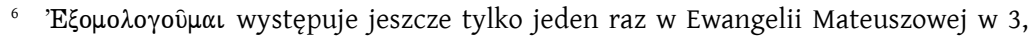
6 (także w stronie zwrotnej) i oznacza tam „wyznawać”, „uznawać”. Regularnie tłumaczy formę sprawczą hebrajskiego czasownika ب̛⿱宀 (yād $\left.\bar{a}^{\mathrm{h}}\right)$ - „czynić znanym”, „ogłaszać”, „wyznawać” oraz „wysławiać” w odniesieniu przede wszystkim do Boga.

7 Podobne w formie hymny dziękczynienia odnajdujemy w pismach qumrańskich (por. 1 QH IV 9, 17, 26; X 20, 31). Por. D. Senior, Matthew, Nashville 1998, s. 132 (Abingdon New Testament Commentaries).

8 Wyrażenie „niebo i ziemia” występuje dość często w Ewangelii Mateuszowej (por. $5,8 ; 6,10.19-20 ; 16,19 ; 18,18.19)$.

9 Por. S. Grasso, Il Vangelo di Matteo, Roma 1995, s. 303 (Collana Biblica). Objawienie Bożych tajemnic zostało dane Danielowi i jego współtowarzyszom, a nie mędrcom babilońskim (por. Dn 2, 27-30). Mądrość odsłania swoje sekrety wiernemu uczniowi (por. Syr 4, 18). 
wyraźnie stwierdza, że Jezus posyłał do Izraela „proroków, mędrców (бoфoús. i uczonych". Werset 25 nie jest więc dowodem z Pisma na antyintelektualizm ${ }^{10}$. Kontrast przebiega bowiem nie między mądrymi, inteligentnymi a dziećmi, lecz pomiędzy pychą uczonych a prostotą dzie$\mathrm{ci}^{11}$. Mądrych i inteligentnych należy utożsamiać w naszym kontekście z uczonymi w Piśmie i faryzeuszami, którzy mają zamkniętą wizję Boga i nie przyjmują nic nowego. Wierzą, że znają wszystko i posiadają właściwą, niezmienną doktrynę. Poprzez swoją samowystarczalność oraz uprzedzenia sami wykluczają się z nowego objawienia się Boga.

Natomiast grecki przymiotnik w formie rzeczownikowej $\nu \eta ́ \pi \iota \varsigma$ („dziecko” ${ }^{12}$ ) jest przeciwieństwem dorosłego ( $\tau \in$ ' $\left.\lambda \in \iota \circ \varsigma\right)$, w znaczeniu zaś metaforycznym opisuje człowieka tak naturalnego, jak dziecko, prostego, zależnego od drugich (por. Rz 2, 20; 1 Kor 13, 11; Ef 4, 14). Termin $\nu \eta ́ \pi ı \varsigma$ („dziecko”) występuje w Ewangelii Mateuszowej jeszcze tylko jeden raz w 21, 16, w kontekście uzdrowienia niewidomych i chromych w świątyni (por. w. 14). Przytoczony tam Ps 8, 3: „Z ust dzieci ( $\nu \eta \pi i \omega \nu)$ i ssących zgotowałeś sobie chwałę", stanowi komentarz do wychwalania Jezusa przez dzieci ( $\pi \alpha \hat{i} \delta \in \varsigma$ - por. 21, 15), które w również w 21, 16 są ukazane w kontraście wobec uczonych w Piśmie (i arcykapłanów), oburzonych na „Syna Dawida” (w. 16).

Ojciec ukrywa przed mądrymi i inteligentnymi „te rzeczy”, nato-

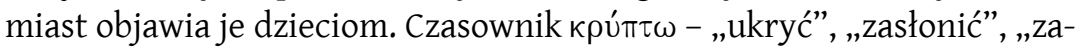
taić", odzwierciedla w naszym przypadku żydowską mentalność, która ignoruje przyczyny pośrednie i przypisuje końcowy rezultat Bożemu

10 Por. C. L. Blomberg, Matthew, Nashville, t. 22, Tennessee 1992, s. 193 (The New American Commentary).

11 Por. D. L. Turner, Matthew, Grand Rapids 2008, s. 303 (Baker Exegetical Commentary on the New Testament). Ostrzeżenie przed „mądrymi” i „inteligentnymi”, którzy nauczając, popadają w arogancję, jest znanym motywem biblijnym. Paweł czyni podobny kontrast pomiędzy „mądrymi” i „głupimi” w 1 Kor 1,18-31 i przytacza w w. 19 słowa: „Wytracę mądrość

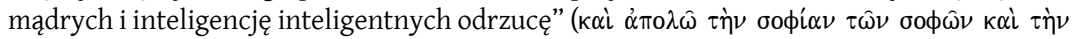

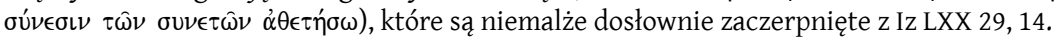

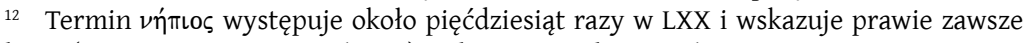
na dzieci (por. np. $1 \mathrm{Sm} \mathrm{15,} \mathrm{3;} 2 \mathrm{Krl} 8,12$ ). Jedynie sporadycznie słowo to przyjmuje znaczenie pejoratywne - „głupiec” (Mdr 12, 24; 15, 14). 
zamysłowi ${ }^{13}$. To nie Ojciec zasłania przed uczonymi „te rzeczy”, lecz wyniosłość mędrców, która sprawia, że ich umysły nie potrafią przeniknąć Bożych zamiarów. Natomiast dzieci, czyli w sensie przenośnym ludzie

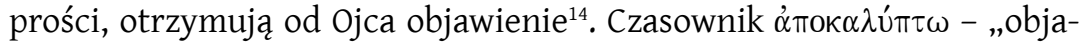
wiać”, „odsłaniać”, „wydobyć na światło”, podkreśla wspaniałomyślność Ojca, który „te rzeczy” czyni dostępnymi, zrozumiałymi dla „małych”. Wybór tej właśnie kategorii ludzi jest upodobaniem Ojca (por. 11, 26).

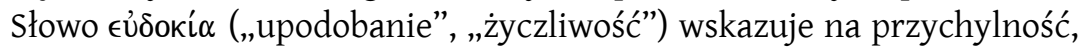
preferencję, jakby słabość Boga, wobec tych, z którymi nikt w świecie się nie liczy ${ }^{16}$.

Rzeczywistość ukryta w wyrażeniu „te rzeczy” ( $\tau \alpha \hat{\tau} \tau \alpha)$ bywa różnie interpretowana. Zaimek wskazujący rodzaju nijakiego $\tau \alpha \hat{\tau} \tau \alpha$ (,te rzeczy") jest bardzo ogólnikowy. Egzegeci dostrzegają w nim między innymi: cały proces objawieniowy realizowany przez Jezusa ${ }^{17}$, wzajemną więź pomiędzy Ojcem i Synem (por. w. 27) ${ }^{18}$ lub otrzymaną przez Jezusa moc i władzę wyrażającą się w nauczaniu i uzdrawianiu ${ }^{19}$. Trudno rozstrzygnąć, jaką opinię należałoby wybrać z przytoczonych możliwości. Wydaje się, że pierwsza jest najbardziej trafna i zawiera w sobie pozostałe dwie. W każdym razie chodzi o prawdę niedostępną dla ludzkiego rozumu, zasłoniętą przed uczonymi, znaną natomiast ludziom prostym, poprzez objawienie dane im od Ojca.

13 Por. W. Trilling, Vangelo secondo Matteo (traduzione dal tedesco di B. da Malè), Roma 20013, s. 200 (Commenti Spirituali del Nuovo Testamento).

14 Nie tylko w Mt 11, 25, ale także często w całej Ewangelii Mateuszowej terminy opisujące małość i dziecięctwo odnoszą się do statusu uczniów (por. 10, 42;18, 2 - 6. 10.14), którzy nie należąc do otoczenia stróżów Prawa, otrzymali objawienie od Boga poprzez samego Jezusa.

15 Również w Starym Testamencie spotykamy teksty mówiące o mądrości udzielanej prostym: por. Ps 19 (18) 8; 119 (118), 130 - LXX w obu tych przypadkach stosuje termin

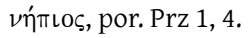

16 Por. W. Trilling, Vangelo secondo Matteo, dz. cyt., s. 200.

17 Por. R.T. France, The Gospel of Matthew, Grand Rapids/Cambridge 2007, s. 443 (The New International Commentary on the New Testament).

18 Por. S. Grasso, Il Vangelo di Matteo, dz. cyt., s. 304.

19 Por. D. Senior, Matthew, dz. cyt., s. 132. 


\section{Wzajemna i tajemnicza znajomość między Ojcem i Synem} (Mt 11, 27)

Jezus wypowiada w dalszym ciągu słowa: „Wszystko przekazał Mi Ojciec mój. Nikt też nie zna Syna, tylko Ojciec, ani Ojca nikt nie zna, tylko Syn, i ten, komu Syn zechce objawić" (w. 27). W cytowanym zdaniu określenia Ojciec oraz Syn występują trzykrotnie. Poza tym dostrzegamy w w. 27bc chiazm, w którego centrum jest Ojciec: A - „Nikt też nie zna Syna”, B - ,tylko Ojciec”, B ${ }^{1}$,ani Ojca nikt nie zna”, A $^{1}$,tylko Syn, i ten, komu Syn zechce objawić".

Ojciec jest więc szczególnie wyeksponowany w Jezusowej modlitwie. Ojca łączy z Synem wyjątkowa relacja wzajemności. Obydwaj znają siebie w sposób pełny. Grecki czasownik é w Biblii zwykłej znajomości. „Znać” zakłada zaangażowanie woli, uczuć i rozumu. „Znać” i „kochać” ściśle łączą się ze sobą ${ }^{21}$. Wzajemna znajomość Ojca z Synem nie jest więc w pierwszym rzędzie znajomością typu intelektualnego, lecz ma charakter głęboko interpersonalny ${ }^{22} \mathrm{i}$ jest oparta na miłości.

Skoro Ojciec dał Synowi wszystko, czyli całe objawienie, wobec tego Syn może nim dysponować i podarować uczestnictwo w nim, komu tylko zechce $^{23}$. Jezus jest bowiem jedynym objawicielem Ojca ${ }^{24}$. Zdanie: „i ten, komu Syn zechce objawić”, stanowi synoptyczny ekwiwalent względem wypowiedzi Jezusa z Ewangelii Janowej: „Nikt nie przychodzi do Ojca inaczej, jak tylko przeze Mnie" (J 14,6). Poznanie Ojca zależy od woli

20 Łukasz stosuje w miejscu paralelnym w 10, 22 czasownik w formie podstawowej $\gamma \iota \nu \omega ́ \sigma \kappa \in \iota$. Przedrostek є̇í wzmacnia czasownik główny („zna całkowicie”), jednak czasow-

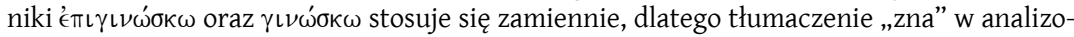
wanym tekście w wersji Mateuszowej jest uzasadnione. Por. J. Nolland, The Gospel of Matthew, Grand Rapids/Cambridge 2005, s. 472 (The International Greek Testament Commentary).

21 Por. W. Trilling, Vangelo secondo Matteo, dz. cyt., s. 201.

22 Por. S. Grasso, Il Vangelo di Matteo, dz. cyt., s. 305.

23 Poznanie Boga nie jest informacją dostępną dla wszystkich (z wyjątkiem Rz 1, 21 w bardzo ograniczonym sensie), lecz specjalnym darem Bożym i łączy się w Nowym Testamencie z wiarą w Jezusa. Por. R.T. France, The Gospel of Matthew, dz. cyt., s. 444.

24 Chrystologia Mateuszowa jest tutaj podobna do Janowej (por. np. J 1, 14. 18; 3, 35; 14 , 6-9; 17, 1-8; por. także 1 Kor 15, 20-28; Ef 1, 9-10); por. A. Paciorek, Ewangelia według świętego Mateusza, Częstochowa 2008, s. 481 (Nowy Komentarz Biblijny, Nowy Testament). 
Syna i jest udzielane, a nie zdobywane przez ludzką inteligencję. Zawsze jednak całe objawienie pozostaje słowem i czynem Ojca. To zatem, co Jezus mówi (także o sobie) i czyni, przychodzi do nas jako dar pochodzący od Boga Ojca ${ }^{25}$.

\section{Moc Ojca i Jego troska o uczniów (Mt 10, 28-31)}

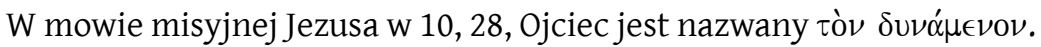
Określenie to będące w tekście greckim w bierniku, odnosi się do sędziowskiej działalności Boga, „który może zniszczyć ciało i duszę w ge-

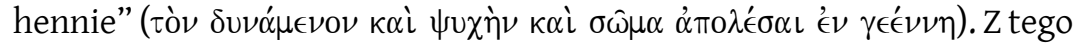
właśnie powodu Jezus napomina, aby bać się Ojca.

Bojaźń Boża ma w tradycji starotestamentowej różnie rozłożone akcenty. Może oznaczać posłuszeństwo (por. Pwt 4, 10; 5, 29), więź z Bogiem (por. Ps 27 [26], 1), miłość i przylgnięcie do Niego (por. Pwt 10, 20), unikanie zła (por. Ps 34 (33), 12. 15). W kontekście Mt 10, 28 przyjmuje natomiast wydźwięk respektu i liczenia się z Ojcem, który posiada nieograniczoną moc i może wymierzyć ostateczną karę ${ }^{26}$.

Ludzka moc względem drugiego ogranicza się do widzialnego ciała, które można zabićn ${ }^{27}$. Nie ma jednak żadnej władzy nad duszą człowieka, czyli nad jego ,ja"28. Dlatego Jezus napomina uczniów, aby w swej misyjnej działalności nie odczuwali strachu przed wrogimi im ludźmi, lecz bali się Ojca, czyli uznawali Jego niepodważalny autorytet.

25 Por. W. Trilling, Vangelo secondo Matteo, dz. cyt., s. 202.

26 Czasownik фоß'́є $\mu \alpha \iota$ - „bać się” występuje w Ewangelii Mateuszowej 18 razy, w tym tylko raz w odniesieniu do Boga, właśnie w analizowanym fragmencie Mt 10, 28. W Łukaszowym tekście paralelnym (por. Łk 12,5) ten sam czasownik pojawia się dwukrotnie. U obu

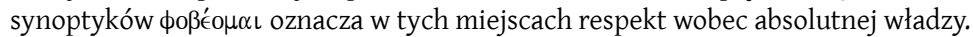

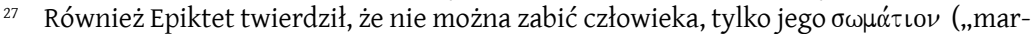
ne ciało"). Por. U. Luz, Das Evangelium nach Matthäus (Mt 8-17), Zürich, Brauschweig, Neukirchen-Vluyn 1990, s. 126, przyp. 27 (Evangelisch-Katholischer Kommentar zum Neuen Testament, 2/4). Autor powołuje się na: Epiktet, Dissertationes, 3, 13, 17.

28 Por. U. Luz, Das Evangelium nach Matthäus (Mt 8-17), dz. cyt., s. 128. Rozróżnienie na ciało, które ludzie mogą zabić oraz duszę, której nie mogą zabić, odzwierciedla wpływ greckiej dychotomicznej antropologii na szerokie kręgi judaizmu. Por. D. Senior, Matthew, dz. cyt., s. 122; A. Paciorek, Ewangelia według świętego Mateusza, t. 1/2, dz. cyt., s. 439. 
Surowa wypowiedź Jezusa, że Bóg może zniszczyć w gehennie (czyli w piekle) ciało i duszę, wzmacnia ogólne przekonanie, że ciało ulega zniszczeniu po śmierci. Natomiast zniszczenie duszy nie jest równoznaczne z unicestwieniem, lecz wyraża jej wieczne męki, jak na to wskazuje słowo „gehenna”29 (por. Mt 5, 22. 29. 30; 18, 9; 23, 33). Termin ten symbolizuje miejsce wiecznej kary. Stanowi transliterację ge-hinnom, czyli doliny Hinnom, która znajdowała się na południe od Jerozolimy (por. $2 \mathrm{Krl} 23,10 ; \mathrm{Jr} 7,31-32 ; 19,1-15$ ). Spalano w niej odpady w nieustannie płonącym ogniu ${ }^{30}$.

Prawda o mocy Boga, który ma absolutną władzę nad człowiekiem i może wydać na niego definitywny i skazujący wyrok, zostaje złagodzona w kolejnym wersecie, czyli w Mt 10, 29, gdzie jest mowa o „waszym Ojcu”, troszczącym się nawet o wróble: „Czyż nie sprzedają dwóch wróbli za asa? A przecież żaden z nich bez Ojca waszego nie spadnie na ziemię”.

Wróble sprzedawano na rynku. Uchodziły za pożywienie dla biedoty. Przysłowie mówiło, że: „Kto godzi się na pracę w ogrodzie, ten je ptaki (ציפָּרִ - şippôrîm)" 31 , czyli najtańszy posiłek. Za dwa asy można było kupić rację chleba na jeden dzień ${ }^{32}$. Moneta „as” była najbardziej zwykłym, miedzianym pieniądzem w rzymskim systemie monetarnym. Jej grecka

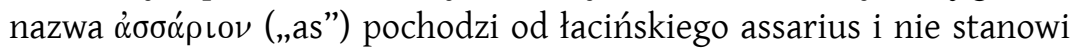
zdrobniałej formy, lecz jest prostym przeniesieniem łacińskiego terminu na język grecki. Wartość asa podaje się w literaturze w zróżnicowany sposób, od 1/24 do 1/16 denara ${ }^{33}$.

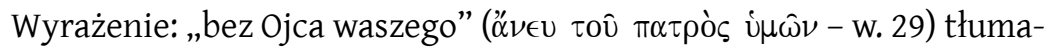
czy się zazwyczaj: „bez wiedzy Ojca waszego”, „bez zgody Ojca waszego” „bez woli Ojca waszego” lub „bez uwagi Ojca waszego”34. Paralelizm względem w. 30: „U was zaś nawet włosy na głowie wszystkie są policzone”

29 Por. C. L. Blomberg, Matthew, dz. cyt., s. 178.

30 Por. S. Grasso, Il Vangelo di Matteo, dz. cyt., s. 284, przyp. 41.

31 Por. U. Luz, Das Evangelium nach Matthäus (Mt 8-17), dz. cyt., s. 128. Autor powołuje się

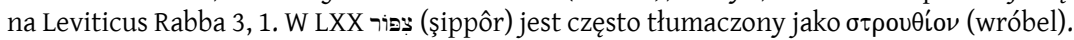

32 Por. U. Luz, Das Evangelium nach Matthäus (Mt 8-17), dz. cyt., s. 128, przyp. 44.

33 Por. U. Luz, Das Evangelium nach Matthäus (Mt 8-17), dz. cyt., s. 128.

34 Por. R.T. France, The Gospel of Matthew, dz. cyt., s. 404. 
sugeruje, aby przyjąć domyślnie „bez wiedzy Ojca”, czyli żaden wróbel „bez wiedzy Ojca waszego nie spadnie na ziemię”.

Stwierdzenie o nieznacznej wartości wróbla przygotowuje żydowską argumentację qal wahomer. Porównuje się w niej dwie rzeczywistości: jedną niższego rzędu, drugą zaś wyższego. To, co jest prawdziwe dla rzeczywistości niższego rzędu, musi być także prawdziwe dla rzeczywistości wyższego rzędu. Skoro Ojciec troszczy się o wróble, to o ileż bardziej będzie się troszczył o swoich uczniów (por. w. 31; por. także 6, 25-34). Również rabini wypowiadali się w podobny sposób: „Żaden wróbel nie ginie bez nieba (czyli bez wiedzy Boga), o ileż bardziej człowiek"35. Wszystko zatem dokonuje się pod znakiem opatrzności Ojca.

Wzmianka o włosach na głowie (por. w. 30) wydaje się być jeszcze bardziej sugestywna od poprzedniego obrazu, ponieważ bezpośrednio

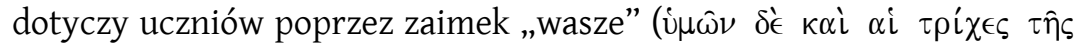

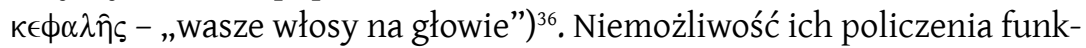
cjonowała jako przysłowie (por. Ps 40 (39), 13; 69 [68], 5) 37. Jednak to, co jest niemożliwe dla człowieka, jest możliwe dla Boga i świadczy o Jego trosce względem ucznia. Jedna z wypowiedzi rabinów głosiła, że Bóg dla każdego pojedynczego włosa na ciele człowieka, uczynił małe wgłębienie $^{38}$. Ojciec przewiduje zatem każdy szczegół.

Analizowane wersety z mowy misyjnej łączą moc Ojca z Jego troską. Te dwa atrybuty są nierozdzielne i tworzą podstawę dla bojaźni Bożej.

35 Por. H.L. Strack, P. Billerbeck, Das Evangelium nach Mattäus erläutert aus Talmud und Midrasch, „Kommentar zum Neuen Testament aus Talmud und Midrasch”, vol. 1, München $1956^{2}$, s. 583.

36 Por. A. Sand, Das Evangelium nach Matthäus, Regensburg 1986, s. 228 (Regensburger Neues Testament).

37 Również wypowiedź: „...jeśli włos z jego głowy spadnie na ziemię” (LXX 1 Sm 14, 45; por. $2 \mathrm{Sm} \mathrm{14,11;} 1 \mathrm{Krl}$ 1, 52), brzmiała jak przysłowie i w podobnej formule występuje także w Łk 21, 18; Dz 27, 34. Por. R.T. France, The Gospel of Matthew, dz. cyt., s. 404.

38 Por. H.L. Strack, P. Billerbeck, Das Evangelium nach Mattäus, dz. cyt., s. 584. Słowa te nawiązują do Hi 38, który razem z Hi 40,6-41, 26 zawiera być może najbardziej wyraziste mowy obronne przemawiające za troską Boga o swoje stworzenie. Por. J. Gnilka, Das Matthäusevangelium. Kommentar zu Kap. 1, 1-13, 58, t. I/1, Freiburg, Basel, Wien 1993, s. 389 (Herders Theologischer Kommentar zum Neuen Testament). 


\section{Zależność uczniów od jedynego Ojca (Mt 23, 9)}

W Mt 23, 9 czytamy, aby nikogo nie nazywać swoim ojcem, ,jeden bowiem jest Ojciec wasz, Ten w niebie". Ważny jest kontekst tego stwierdzenia. W Mt 23, 1 Jezus zwraca się do tłumów oraz do swoich uczniów i przestrzega, aby nie wypaczali religii, jak to czynią uczeni w Piśmie i faryzeusze. Wcześniej w Mt 15, 1-20 obnażył doktrynę duchowych przewodników Izraela, teraz zaś w Mt 23 demaskuje między innymi ich głód popularności i uznania (por. 23, 5).

W Mt 23, 8, czyli w wersecie poprzedzającym analizowaną przez nas wypowiedź o wyłącznym ojcostwie Boga, Jezus napomina, aby nie pozwalać nazywać się „rabbi”. Hebrajski termin „rabbi” zawiera w sobie przymiotnik רַ (rab - ,wielki”) i oznacza „mój mistrzu”. Wskazywał też na większą godność (por. Mt 23, 7). Natomiast w Mt 23, 10, czyli w wersecie występującym zaraz po rozważanym przez nas stwierdzeniu, Jezus

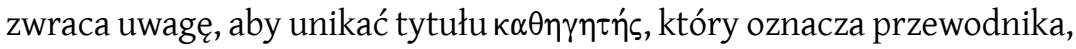
kogoś, kto wskazuje drogę. Zazwyczaj stosowano go odnośnie do nauczycieli, czyli tych, którzy pokazują drogę w sposób intelektualny i duchowy. Nasz termin „mentor” mógłby być jego synonimem ${ }^{39}$.

Zasygnalizowane ww. 8. 10 tworzą obramowanie dla centralnego pouczenia, że tytuł „Ojciec” jest zastrzeżony jedynie dla Boga. Prawda o wyłącznym ojcostwie Bożym nie jest równoważna z rezygnacją z odniesienia do biologicznego ojca (por. np. Mt 2, 22; 4, 21. 22; 8, 21), ani też z zawieszeniem relacji do duchowego ojcostwa (por. Dz, 22, 1), czy też z utratą świadomości, że jest się ojcem czyjeś wiary (por. 1 Kor 4, 15; por. także Flm 10).

W Kościele, którego reprezentantem jest Mateusz, wszyscy są braćmi (por. Mt 18, 15-16; 23, 8). Nie ma w nim ojców, w sensie zależności od kogoś albo okazywanych komuś szczególnych względów. Nie ma w nim także mistrzów, nauczycieli cieszących się większym uznaniem od innych. Nie ma też relacji typu wyższy - niższy ${ }^{40}$. Wszyscy są równi, ponieważ mają jednakowe odniesienie i zależność od jedynego Ojca w niebie.

39 Por. R.T. France, The Gospel of Matthew, dz. cyt., s. 864.

40 Por. S. Grasso, Il Vangelo di Matteo, dz. cyt., s. 542. 


\section{Zakończenie}

Analiza wybranych tekstów (Mt 11, 25-27; 10, 28-31; 23, 9) pozwala wyciągnąć pewne sugestie dotyczące ojcostwa Bożego. Ojciec, Pan nieba i ziemi, pozostaje niedostępnym misterium dla człowieka. Nie pozostawia go jednak w ciemności, gdy spotka się z jego strony z poczuciem niewystarczalności, małości. Wówczas objawia mu „te rzeczy”, czyli prawdy niedostępne dla ludzkiego rozumu, które z kolei zakrywa przed wyniosłymi, zamkniętymi w swych doktrynach.

Pełna znajomość Ojca jest atrybutem jedynie Syna i odwrotnie. Całkowita znajomość Syna przysługuje tylko Ojcu. W przypadku ludzi, poznanie Ojca (miłość do Niego) jest także zależne od woli Syna i domaga się prostoty dziecka.

Ojciec dysponuje mocą i ma władzę nad człowiekiem oraz jego ostatecznym losem. Należy więc liczyć się z Jego absolutnym, rozstrzygającym autorytetem. Zalecana bojaźń wyraża się w tym przypadku w respekcie wobec Niego. Tego typu postawa jest również motywowana i jednocześnie złagodzona troską Ojca, podkreśloną przez argumentację qal wahomer: skoro Bóg troszczy się o wróble, to tym bardziej zabiega o człowieka.

Świadomość całkowitej zależności od Ojca podpowiada, aby nie hołdować w eklezjalnej wspólnocie żadnym przywilejom, które mogłyby wynikać z poczucia wyższości i przewagi nad kimś. W Chrystusowym Kościele wszystkie relacje mają opierać się na powszechnym braterstwie.

Wydobyte prawdy dotyczące ojcostwa Bożego są, jak czytamy w tytule artykułu, aspektami tego tematu. Wprowadzają w zagadnienie, dlatego należy je przyjąć bardziej jako intuicje niż ostateczne wnioski.

\section{Bibliografia}

Blomberg C.L., Matthew, Nashville 1992 (The New American Commentary, 22).

France R.T., The Gospel of Matthew, Cambridge 2007 (The New International Commentary on the New Testament).

Gnilka J., Das Matthäusevangelium. Kommentar zu Kap. 1, 1-13, 58, Freiburg, Basel, Wien 1993 (Herders Theologischer Kommentar zum Neuen Testament, 1/1).

Grasso S., Il Vangelo di Matteo, Roma 1995 (Collana Biblica).

Kwas A., Bóg Ojcem w Nowym Testamencie, „Ruch Biblijny i Liturgiczny” 35 (1982) nr 3, s. 186-193. 
Langkammer H., Bógjako Ojciec w świetle Nowego Testamentu, Radom 1999.

Luz U., Das Evangelium nach Matthäus (Mt 8-17), Zürich, Brauschweig, Neukirchen-Vluyn 1990 (Evangelisch-Katholischer Kommentar zum Neuen Testament, 2/4).

Mickiewicz F., Ty, Panie, jesteś naszym Ojcem (Iz 64, 7). Biblia o Bogu Ojcu, red. J. Warzecha, Warszawa 1999 (Rozprawy i Studia Biblijne, 5).

Nolland J., The Gospel of Matthew, Grand Rapids/Cambridge 2005 (The International Greek Testament Commentary).

Paciorek A., Ewangelia według świętego Mateusza, Częstochowa 2006 (Nowy Komentarz Biblijny. Nowy Testament, 1/2).

Rosik M., Teologia Nowego Testamentu, t. 1: Ewangelie synoptyczne i Dzieje Apostolskie, Wrocław 2008.

Sand A., Das Evangelium nach Matthäus, Regensburg 1986 (Regensburger Neues Testament).

Senior D., Matthew, Nashville 1998 (Abingdon New Testament Commentaries).

Strack H. L., Billerbeck P., Das Evangelium nach Mattäus erläutert aus Talmud und Midrasch, München $1956^{2}$ (Kommentar zum Neuen Testament aus Talmud und Midrasch, 1).

Trilling W., Vangelo secondo Matteo (traduzione dal tedesco di B. da Malè), Roma $2001^{3}$ (Commenti Spirituali del Nuovo Testamento).

Turner D. L., Matthew, Grand Rapids 2008 (Baker Exegetical Commentary on the New Testament).

Witkowski S., Nowa jakość życia. Kazanie na Górze (Mt 5-7), Kraków 2004. 